\title{
Glycolipids from seaweeds and their potential biotechnological applications
}

\author{
Erwan Plouguerné ${ }^{1 *}$, Bernardo A. P. da Gama ${ }^{1}$, Renato C. Pereira ${ }^{1}$ and Eliana Barreto-Bergter ${ }^{2}$ \\ Laboratório de Produtos Naturais e Ecologia Química Marinha, Departamento de Biologia Marinha, Instituto de Biologia, Universidade Federal Fluminense, \\ Niterói, Brazil \\ ${ }^{2}$ Laboratório de Química Biológica de Microrganismos, Departamento de Microbiologia Geral, Instituto de Microbiologia, Universidade Federal do Rio de Janeiro, \\ Rio de Janeiro, Brazil
}

\section{Edited by:}

Yongqun He, University of Michigan

Medical School, USA

Reviewed by:

Janakiram Seshu, The University of

Texas at San Antonio, USA

Vincent Joseph Starai, The

University of Georgia, USA

*Correspondence:

Erwan Plouguerné, Laboratório de

Produtos Naturais e Ecologia

Química Marinha, Departamento de

Biologia Marinha, Instituto de

Biologia, Universidade Federal

Fluminense, Campus do

Valonguinho, Outeiro São João

Batista s/n, Centro, Niterói,

RJ 24001-970, Brazil

e-mail: eplouguerne@hotmail.com
Marine macroalgae, or seaweeds, are a formidable source of natural compounds with diverse biological activities. In the last five decades it has been estimated that more than 3000 natural compounds were discovered from these organisms. The great majority of the published works have focused on terpenoids. In comparison, glycolipids are a neglected class of macroalgal secondary metabolites therefore remaining as a largely unknown reservoir of molecular diversity. Nevertheless, the interest regarding these compounds has been growing fast in the last decades as activities of ecological or pharmaceutical interest have been highlighted. This paper will review recent work regarding isolation and structural characterization of glycolipids from seaweeds and their prospective biological activities.

Keywords: seaweeds, glycolipids, MGDG, DGDG, SODG, biological activity, marine macroalgae

\section{INTRODUCTION}

For the last five decades, both chemists and biologists have carried out an intense effort regarding marine natural products (Bhakuni and Rawat, 2005; Blunt et al., 2014). Such dedication has resulted in the discovery of more than 20,000 compounds from marine microorganisms, invertebrates, and macroalgae (Hu et al., 2011). Marine organisms appear then as a formidable source of natural products. While products of primary metabolism like amino acids, carbohydrates and proteins, are vital for maintaining life processes, others such as alkaloids, phenolics, steroids, terpenoids, are secondary metabolites that have ecological, toxicological, and pharmacological significance (Maschek and Baker, 2008). Bioactivities such as antiherbivory, antifoulant, antifungal, antitumor, antimicrobial, and antiparasitic effects have been highlighted for marine natural products (Noda et al., 1990; Deal et al., 2003; Bhadury and Wright, 2004; Cheung et al., 2014).

With an estimation of more than 30,000 species identified around the world, marine macroalgae, or seaweeds, constitute a huge source of natural compounds with diverse biological activities (Guiry, 2012). In the last 50 years it has been estimated that more than 3000 natural compounds were discovered from these organisms (Leal et al., 2013). The great majority of the published works have focused on terpenoids, phenolic compounds, or polysaccharides. Glycolipids represent a less studied class of metabolites with recently growing interest. Seaweeds biosynthesize three major types of glycolipids: monogalactosyldiacylglycerides (MGDGs), digalactosyldiacylglycerides (DGDGs), and sulfoquinovosyldiacylglycerides (SQDGs) (Figure 1).
These glycoglycerolipids are present in chloroplasts of eukaryotic algae where MGDGs and DGDGs are the most abundant lipids of the thylakoid membrane and appear to play a crucial role in photosynthesis (Hölzl and Dörmann, 2007).

This work will present a concise review of studies from the last 15 years regarding the isolation and structural characterization of bioactive glycolipids from marine macroalgae.

\section{OCHROPHYTA}

The MGDG isolated from Petalonia binghamiae was characterized as a potent inhibitor of the activities of mammalian DNA polymerase $\alpha$ (Mizushina et al., 2001).

SQDG and DGDG from the Japanese macroalga Sargassum horneri were found to induce apoptosis of the human colon carcinoma Caco-2 cell when associate with sodium butyrate (Hossain et al., 2005).

The acetone fraction of Sargassum thunbergii extract exhibited moderate antifungal effects on Candida albicans. Further investigation of this extract led to the isolation of four MGDGs, two of them newly described as (2S)-1-O-(5Z,8Z, $11 Z, 14 Z, 17 Z$-eicosapentaenoyl)-2-O-(9Z,12Z,15Z-octadecatrien oyl)-3-O- $\beta$-D-galactopyranosyl- sn-glycerol and (2S) -1-O(9Z,12Z, 15Z-octadecatrienoyl)-2-O-(6Z,9Z,12Z,15Z-octad ecatetraenoyl)-3-O- $\beta$-D-galactopyranosyl-sn-glycerol (Kim et al., 2007).

Two glucopyranosyldiacylglycerols were isolated from Sargassum fulvellum. The two compounds were identified to be 1-O-palmitoyl-2-O-oleoyl-3-O-( $\alpha$-D-glucopyranosyl)-glycerol 


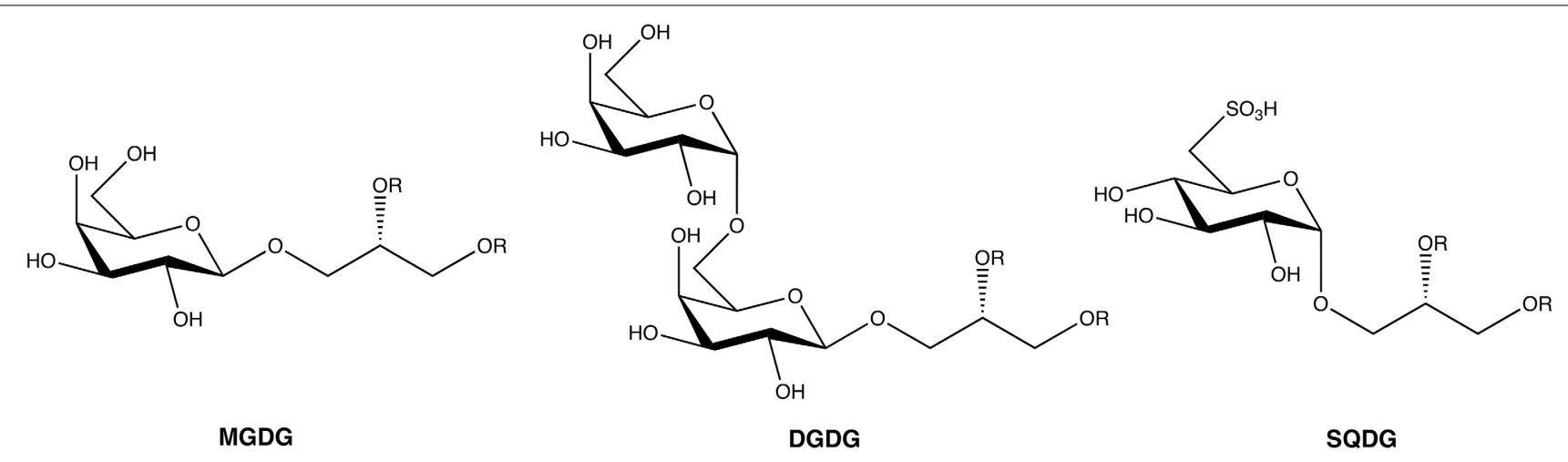

FIGURE 1 | General structure of the three main glycoglycerolipids from seaweeds. R, acyl chain.

and 1-O-myristoyl-2-O-oleoyl-3-O-( $\alpha$-glucopyranosyl)-glycerol and showed fibrinolytic activity in the reaction system of single chain urokinase-type plasminogen activator and plasminogen (Wu et al., 2009).

The dichloromethane-methanol (7/3) extract of Lobophora variegata from the Yucatan coast (Mexico) demonstrated activity against the protozoa Trichomonas vaginalis, with an $\mathrm{IC}_{50}$ value of $3.2 \mu \mathrm{g} / \mathrm{ml}$ (Cantillo-Ciau et al., 2010). Further fractionation of that extract was undergone and led to a chloroform fraction that showed activity against the protozoa T. vaginalis, Giardia intestinalis, and Entamoeba histolytica, with good selectivity $(S I>10)$. Purification of this fraction allowed the isolation of three SQDGs: the major compound 1-O-palmitoyl-2$O$-myristoyl-3-O-(6-sulfo- $\alpha$-D-quinovopyranosyl)-glycerol, along with small amounts of 1,2-di-O-palmitoyl-3-O-(6sulfo- $\alpha$-D-quinovopyranosyl)-glycerol and a new compound identified as 1-O-palmitoyl-2-O-oleoyl-3-O-(6-sulfo- $\alpha-\mathrm{D}$ quinovopyranosyl)-glycerol.

Plouguerné et al. (2010) isolated MGDGs in a fraction obtained from Sargassum muticum collected from the coast of Britanny (France), that inhibited the bacteria Shewanella putrefaciens and Polaribacter irgensii and the fungi Halosphaeriopsis mediosetigera, Asteromyces cruciatus, Lulworthia uniseptata, Monodictys pelagica, all involved in marine microfouling. The inhibitory activity was reported for a concentration of $0.75 \mathrm{mg} / \mathrm{l}$.

The crude ethyl acetate extract of Fucus evanescens, collected on the Arctic coast of Ungava Bay, Nunavik (Canada), showed strong antibacterial activity $\left(\geq 4 \log _{10}\right.$ colony-forming units (cfu) against Hemophilus influenza, Legionella pneumophila, Propionibacterium acnes, and Streptococcus pyogenes, when tested at $100 \mu \mathrm{g} / \mathrm{ml}$. This glycolipid rich extract also inhibited by 3 $\log _{10}$ cfu the bacteria Clostridium difficile and Staphylococcus aureus (Amiguet et al., 2011). Further purification of the glycolipid rich extract led to the isolation and identification of the main compound as the MGDG $2^{\prime}, 3^{\prime}$-propyl dilinolenate- $\beta$-Dgalactopyranoside.

El Baz et al. (2013) investigated the structures and biological activities of sulfolipids from the Mediterranean macroalgae Dilophus fasciola and Taonia atomaria. The authors highlighted antibacterial and antiviral activities from sulfolipids extracts. The major compounds were identified as SQDG and SQMG (sulfoquinovosylmonoacylglyceride).

SGDGs were identified in fractions obtained after the purification of the organic extract of the Brazilian macroalga Sargassum vulgare. The main SQDG responsible for the antiHSV1 and anti-HSV2 activities highlighted was characterize as 1, 2-di-O-palmitoyl-3-O-(6-sulfo- $\alpha$-D-quinovopyranosyl)-glycerol (Plouguerné et al., 2013). The structure of the SQDG was determined using Electrospray Ionization Mass Spectrometry (ESI-MS) (Figure 2A) and the configuration of the anomeric carbon was confirmed by ${ }^{1} \mathrm{H}$ and ${ }^{13} \mathrm{C}$ Nuclear Magnetic Resonance (NMR) analysis, based on Heteronuclear Single Quantum Coherence (HSQC) fingerprints (Figure 2B).

Imbs et al. (2013) isolated a highly unsaturated monogalactosyldiacylglycerol (MGDG) from the ethanol extract of Fucus evanescens, collected from the west coast of the Iturup Island of the Sea of Okhotsk (Russia). This compound, identified as $1-O-(5 Z, 8 Z, 11 Z, 14 Z, 17 Z$-eicosapentanoyl)-2-O-(6Z,9Z,12Z, $15 Z$-octadecatetraenoyl)-3-O- $\beta$-D-galactopyranosyl-sn-glycerol, inhibited the growth of human melanoma cells with an $\mathrm{IC}_{50}=$ $104 \mu \mathrm{M}$.

\section{RHODOPHYTA}

Ohta et al. (1998) isolated the SQDG KM043 from Gigartina tenella, collected at Sagami Bay, Kanagawa, Japan, that demonstrated inhibition of DNA polymerase $\alpha$, DNA polymerase $\beta$ and HIV-reverse transcriptase type 1 , with respective IC $_{50}$ values of $0.25,3.6$, and $11.2 \mu \mathrm{M}$. The structure of the SQDG was identified as 1-(1'-O- $\alpha$-D-sulfoquinovosyl)-2-palmitoyl-3-[5" (E), $8^{\prime \prime}$ (E), $11^{\prime \prime}(\mathrm{E}), 14^{\prime \prime}(\mathrm{E}), 17^{\prime \prime}(\mathrm{E})$-eicosapentaenyl]-syn-glycerol.

Al-Fadhli et al. (2006) isolated three distinct fractions containing polar glycolipids from the soluble fraction of crude methanolic extract of Chondria armata. The structure of the glycolipids was elucidated using multidimensional NMR techniques and ESI-MS in the positive ion mode. The most active fraction showed significant growth inhibition of the bacteria Klebsiella sp., the yeast Candida albicans and the fungus Cryptococcus neoformans when tested at the concentration of $130 \mu \mathrm{g} / \mathrm{disc}$. The main compound present in the fraction was identified as the MGDG 1-eicosapentanoyl-2-palmitoyl-3-O-galactopyranosylglycerol. 


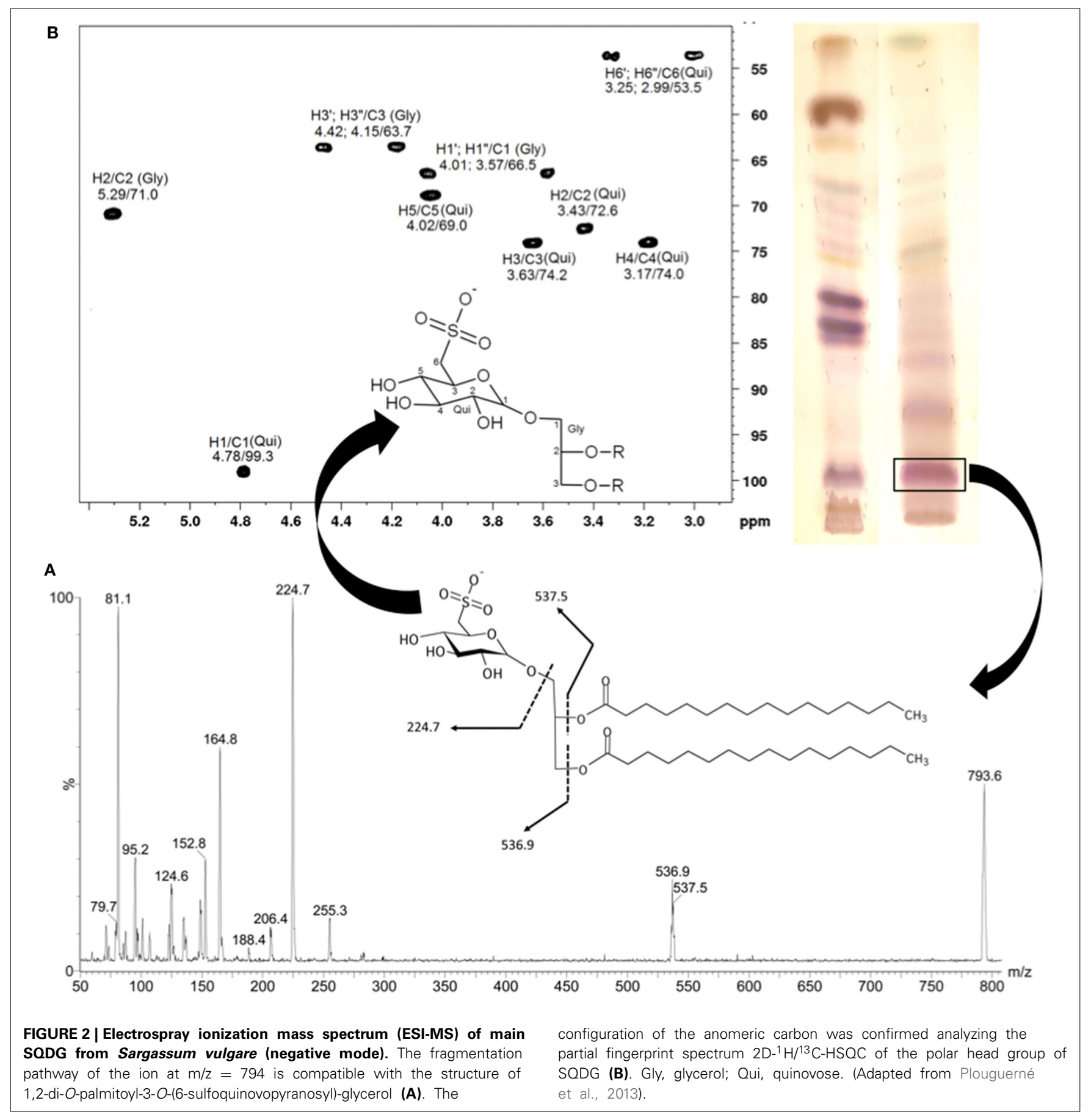

The MGDG lithonoside isolated from the cytotoxic hexanesoluble extract of the Fijian coralline macroalga Hydrolithon reinboldii demonstrated moderate growth inhibitory activity against cancer cell lines with a mean $\mathrm{IC}_{50}$ value of $19.8 \mu \mathrm{M}$ (Jiang et al., 2008).

de Souza et al. (2012) isolated an anti-HSV (herpes simplex virus) glycolipid-enriched fraction from the Brazilian macroalga Osmundaria obtusiloba. The major compound of the active fraction was identified as the SQDG 1,2-di-O-acyl-3-O-(6-deoxy6-sulfo- $\alpha$-D-glucopyranosyl)-sn-glycerol.
Tsai and Pan (2012) isolated SQDGs from Porphyra crispata collected from northeastern Taiwan that inhibited the growth of human hepatocellular carcinoma cell line (HepG2), with an IC50 of $126 \mu \mathrm{g} / \mathrm{ml}$.

El Baz et al. (2013) investigated the structures and biological activities of sulfolipids from Laurencia papillosa and Galaxaura cylindrica collected from the Red Sea. The authors highlighted antibacterial and antiviral activities from sulfolipids extracts. The major compounds were identified as SQDG and SQMG. 
Anti-inflammatory activity was highlighted for two SQDGs isolated from Palmaria palmata (Banskota et al., 2014). The bioactive compounds were identified as (2S)-1-O-eicosapentaenoyl-2-O-myristoyl-3-O-(6-sulfo-a-D-quinovopyranosyl)-glycerol and (2S)-1-O-eicosapentaenoyl-2-Opalmitoyl-3-O-(6-sulfo- $\alpha$-D-quinovopyranosyl)-glycerol and demonstrated nitric oxide inhibitory activity with $\mathrm{IC}_{50}$ values of 36.5 and $11.0 \mu \mathrm{M}$, respectively.

\section{CHLOROPHYTA}

Wang et al. (2007) isolated a SQDG from the n-butanol fraction of the invasive Caulerpa racemosa collected from the South China Sea. The SQDG compound was characterized using spectroscopic methods as (2S)-1,2-di-O-palmitoyl-3-O-(6'-sulfo- $\alpha$ D-quinovopyranosyl) glycerol, and was active against HSV-2, with a $50 \%$ inhibitory concentration $\left(\mathrm{IC}_{50}\right)$ of $15.6 \mathrm{mg} \mathrm{m} \mathrm{m}^{-1}$ against both standard and clinical strains of HSV-2.

MGDGs capsofulvesin A and B, along with the MGMG capsofulvesin C, isolated from Capsosiphon fulvescens collected from the southern coastal area of Wando (Korea), demonstrated cholinesterase inhibitory activity (Fang et al., 2012).

Islam et al. (2014) revealed for the first time the aldose reductase inhibitory activity of the capsofulvesin $A$ and capsofulvesin B.

Such results highlighted the potential health benefits of $C$. fulvescens in improving neurotransmission as well as in preventing diabetic complications.

El Baz et al. (2013) investigated the structures and biological activities of sulfolipids from the Mediterranean macroalga Ulva fasciata. The authors highlighted antibacterial and antiviral activities from sulfolipids extracts, and the major compounds were identified as SQDG and SQMG.

\section{CONCLUSION}

Among the three phyla of marine macroalgae, Ochrophyta appears as the main source of recently reported bioactive glycolipids, followed by Rhodophyta and Chlorophyta. Within Ochrophyta, the order Fucales was the most reported, followed by Dictyotales.

Among bioactive glycolipids isolated from marine macroalgae, SQDGs, and MGDGs dominated the reports for the last 15 years. Khotimchenko (2003) studied the distribution of glyceroglycolipids in marine macroalgae and highlighted the predominance of SQDG as a characteristic of brown seaweeds from the order Fucales. It would then be logical to expect such order as a major source of bioactive SQDGs. However, according to the recent literature, bioactive SQDGs were more abundant in Dictyotales.

The most reported biological activities for glycolipids from seaweeds were antibacterial, antitumor, and antiviral activities, enhancing the pharmacological potential of these compounds. Less reported, but of significant interest, is the ecological role that may assume glycolipids biosynthetized by seaweeds. Antifouling, and antiherbivory activities were already reported for glycolipids from Sargassum muticum and Fucus vesiculosus, respectively (Deal et al., 2003; Plouguerné et al., 2010).

Concerning the mechanism of action of glycolipids, it remains until today relatively obscure. Recent studies about synthesis and structural modification of glycoglycerolipids helped to understand the structure-activity relationship. On general point of view, the bioactivities of glycoglycerolipids are related to the sugar moiety, the position of the glycerol linkage to the sugar, the length and location of the acyl chain, and the anomeric configuration of the sugar (Zhang et al., 2014). Polyunsaturated fatty acids (PUFAs) are biologically active compounds, which are abundant components of macrophytic glycolipids (Khotimchenko, 1993a,b, 2003; Sanina et al., 2000, 2004; Raposo et al., 2013). Therefore, it has been hypothesize that fatty acids may be responsible for biological activities highlighted from macrophytic glycolipids (Tsai and Pan, 2012). As the distribution of PUFAs in glycolipids from seaweeds depends from their taxonomic position, it may then be logical to expect some taxa to be more active than others (Sanina et al., 2004). Among glycolipids, the degree of saturation of fatty acid increased in the lines of MGDG->DGDG->SQDG. Concerning SQDGs, the antiviral activity may be related to the presence of the sulfonate group (Plouguerné et al., 2013). The sulfate moiety along with the nature of the fatty acids of the SQDGs are also important for the inhibition of DNA polymerase $\alpha$ and $\beta$ (Mizushina et al., 1996, 1997; Hanashima et al., 2000, 2001).

Glycoglycerolipids from seaweeds are compounds with both biotechnological potential and ecological interest. Further studies are needed to extend knowledge concerning the mechanism of action of these molecules as well as their distribution between macroalgal species.

\section{ACKNOWLEDGMENTS}

This work was supported by FAPERJ (Fundação de Amparo à Pesquisa do Estado do Rio de Janeiro), CNPq (Conselho Nacional de Desenvolvimento Científico e Tecnológico), CAPESProex (Programa de Excelência Acadêmica da Coordenação de Aperfeiçoamento de Pessoal de Nível Superior), Universidade Federal do Rio de Janeiro (UFRJ) and Universidade Federal Fluminense (UFF). Bernardo A. P. da Gama, Renato C. Pereira, and Eliana Barreto-Bergter are CNPq research fellows.

\section{REFERENCES}

Al-Fadhli, A., Wahidulla, S., and D'Souza, L. (2006). Glycolipids from the red alga Chondria armata (Kutz.) Okamura. Glycobiology 16, 902-9155. doi: 10.1093/glycob/cwl018

Amiguet, V. T., Jewell, L. E., Mao, H., Sharma, M., Hudson, J. B., Durst, T., et al. (2011). Antibacterial properties of a glycolipid-rich extract and active principle from Nunavik collections of the macroalgae Fucus evanescens C. Agardh (Fucaceae). Can. J. Microbiol. 57, 745-749. doi: 10.1139/w11-065

Banskota, A. H., Stefanova, R., Sperker, S., Lall, S. P., Craigie, J. S., Hafting, J. T., et al. (2014). Polar lipids from the marine macroalga Palmaria palmata inhibit lipopolysaccharide-induced nitric oxide production in RAW264.7 macrophage cells. Phytochemistry 101, 101-108. doi: 10.1016/j.phytochem.2014.02.004

Bhadury, P., and Wright, P. C. (2004). Exploitation of marine algae: biogenic compounds for potential antifouling applications. Planta 219, 561-578. doi: 10.1007/s00425-004-1307-5

Bhakuni, D. S., and Rawat, D. S. (2005). Bioactive Marine Natural Products. New York, NY: Springer; New Delhi: Anamaya Publishers.

Blunt, J. W., Copp, B. R., Keyzers, R. A., Munro, M. H. G., and Prinsep, M. R. (2014). Marine natural products. Nat. Prod. Rep. 31, 160-258. doi: $10.1039 / \mathrm{c} 3 \mathrm{np} 70117 \mathrm{~d}$

Cantillo-Ciau, Z., Moo-Puc, R., Quijano, L., and Freile-Pelegrin, Y. (2010). The tropical brown alga Lobophora variegata: a source of antiprotozoal compounds. Mar. Drugs 8, 1292-1304. doi: 10.3390/md8041292 
Cheung, R. C. F., Wong, J. H., Pan, W. L., Chan, Y. S., Yin, C. M., Dan, X. L., et al. (2014). Antifungal and antiviral products of marine organisms. Appl. Microbiol. Biot. 98, 3475-3494. doi: 10.1007/s00253-014-5575-0

Deal, M. S., Hay, M. E., Wilson, D., and Fenical, W. (2003). Galactolipids rather than phlorotannins as herbivore deterrents in the brown seaweed Fucus vesiculosus. Oecologia 136, 107-114. doi: 10.1007/s00442-003-1242-3

de Souza, L. M., Sassaki, G. L., Villela Romanos, M. T., and Barreto-Bergter, E. (2012). Structural Characterization and Anti-HSV-1 and HSV-2 Activity of glycolipids from the marine algae Osmundaria obtusiloba isolated from southeastern Brazilian coast. Mar. Drugs 10, 918-931. doi: 10.3390/md10040918

El Baz, F. K., El Baroty, G. S., Abd El Baky, H. H., Abd El-Salam, O. I., and Ibrahim, E. A. (2013). Structural characterization and biological activity of sulfolipids from selected marine algae. Grasas Aceites 64, 561-571. doi: 10.3989/gya.050213

Fang, Z., Jeong, S. Y., Jung, H. A., Choi, J. S., Min, B. S., and Woo, M. H. (2012). Capsofulvesins A-C, cholinesterase inhibitors from Capsosiphon fulvescens. Chem. Pharm. Bull. 60, 1351-1358. doi: 10.1248/cpb.c12-00268

Guiry, M. D. (2012). How many species of algae are there? J. Phycol. 48, 1057-1063. doi: 10.1111/j.1529-8817.2012.01222.x

Hanashima, S., Mizushina, Y., Ohta, K., Yamazaki, T., Sugawara, F., and Sakaguchi, K. (2000). Structure-activity relationship of a novel group of mammalian DNA polymerase inhibitors, synthetic sulfoquinovosylacylglycerols. Cancer Sci. 91, 1073-1083. doi: 10.1111/j.1349-7006.2000.tb00887.x

Hanashima, S., Mizushina, Y., Yamazaki, T., Ohta, K., Takahashi, S., Sahara, H., et al. (2001). Synthesis of sulfoquinovosylacylglycerols, inhibitors of eukaryotic DNA polymerase $\alpha$ and $\beta$. Bioorg. Med. Chem. 9, 367-376. doi: 10.1016/S09680896(00)00252-2

Hölzl, G., and Dörmann, P. (2007). Structure and function of glycoglycerolipids in plants and bacteria. Prog. Lipid Res. 46, 225-243. doi: 10.1016/j.plipres.2007.05.001

Hossain, Z., Kurihara, H., Hosokawa, M., and Takahashi, K. (2005). Growth inhibition and induction of differentiation and apoptosis mediated by sodium butyrate in Caco-2 cells with algal glycolipids. In Vitro Cell. Dev. Biol. Anim. 41, 154-159. doi: 10.1290/0409058.1

Hu, G.-P., Yuan, J., Sun, L., She, Z.-G., Wu, J.-H., Lan, X.-J., et al. (2011). Statistical research on marine natural products based on data obtained between 1985 and 2008. Mar. Drugs 9, 514-525. doi: 10.3390/md9040514

Imbs, T. I., Ermakova, S. P., Fedoreyev, S. A., Anastyuk, S. D., and Zvyagintseva, T. N. (2013). Isolation of Fucoxanthin and highly unsaturated monogalactosyldiacylglycerol from brown alga Fucus evanescens C Agardh and in vitro investigation of their antitumor activity. Mar. Biotechnol. 15, 606-612. doi: 10.1007/s10126-013-9507-2

Islam, M. N., Choi, S. H., Moon, H. E., Park, J. J., Jung, H. A., Woo, M. H., et al. (2014). The inhibitory activities of the edible green alga Capsosiphon fulvescens on rat lens aldose reductase and advanced glycation end products formation. Eu. J. Nutr. 53, 233-242. doi: 10.1007/s00394-013-0521-y

Jiang, R. W., Hay, M. E., Fairchild, C. R., Prudhomme, J., Le Roch, K., Aalbersberg, W., et al. (2008). Antineoplastic unsaturated fatty acids from Fijian macroalgae. Phytochemistry 69, 2495-2500. doi: 10.1016/j.phytochem.2008.07.005

Khotimchenko, S. V. (1993a). Fatty-acids of green macrophytic algae from the sea of Japan. Phytochemistry 32, 1203-1207. doi: 10.1016/S0031-9422(00) 95092-1

Khotimchenko, S. V. (1993b). Fatty-acids and polar lipids of seagrasses from the sea of Japan. Phytochemistry 33, 369-372. doi: 10.1016/0031-9422(93)85520-2

Khotimchenko, S. V. (2003). The Fatty acid composition of glycolipids of marine macrophytes. Russ. J. Mar. Biol. 29, 126-128. doi: 10.1023/A:1023960 825983

Kim, Y. H., Kim, E. H., Lee, C., Kim, M. H., and Rho, J. R. (2007). Two new monogalactosyl diacylglycerols from brown alga Sargassum thunbergii. Lipids 42, 395-399. doi: 10.1007/s11745-007-3035-7

Leal, M. C., Munro, M. H. G., Blunt, J. W., Puga, J., Jesus, B., Calado, R., et al. (2013). Biogeography and biodiscovery hotspots of macroalgal marine natural products. Nat. Prod. Rep. 30, 1380-1390. doi: 10.1039/c3np70057g

Maschek, J. A., and Baker, B. J. (2008). "The chemistry of algal secondary metabolism," in Algal Chemical Ecology, ed C. D. Amsler (Berlin: SpringerVerlag), 1-24.
Mizushina, Y., Sugiyama, Y., Yoshida, H., Hanashima, S., Yamazaki, T., Kamisuki, S., et al. (2001). Galactosyldiacylglycerol, a mammalian DNA polymerase alpha-specific inhibitor from a sea alga, Petalonia bingbamiae. Biol. Pharm. Bull. 24, 982-987. doi: 10.1248/bpb.24.982

Mizushina, Y., Tanaka, N., Yagi, H., Kurosawa, T., Onoue, M., Seto, H., et al. (1996). Fatty acids selectively inhibit eukaryotic DNA polymerase activities in vitro. Biochim. Biophys. Acta 1308, 256-262. doi: 10.1016/0167-4781(96)00121-2

Mizushina, Y., Yoshida, S., Matsukage, A., and Sakaguchi, K. (1997). The inhibitory action of fatty acids on DNA polymerase $\beta$. Biochim. Biophys. Acta 1336, 509-521. doi: 10.1016/S0304-4165(97)00067-6

Noda, H., Amano, H., Arashima, K., and Nisizawa, K. (1990). Antitumor activity of marine algae. Hydrobiologia 204, 577-584. doi: 10.1007/BF00040290

Ohta, K., Mizushina, Y., Hirata, N., Takemura, M., Sugawara, F., Matsukage, A., et al. (1998). Sulfoquinovosyldiacylglycerol, KM043, a new potent inhibitor of eukaryotic DNA polymerases and HIV-reverse transcriptase type 1 from a marine red alga, Gigartina tenella. Chem. Pharm. Bull. 46, 684-686. doi: $10.1248 /$ cpb.46.684

Plouguerné, E., de Souza, L. M., Sassaki, G. L., Cavalcanti, J. F., Villela Romanos, M. T., da Gama, B. A. P., et al. (2013). Antiviral sulfoquinovosyldiacylglycerols (SQDGs) from the brazilian brown seaweed Sargassum vulgare. Mar. Drugs 11, 4628-4640. doi: 10.3390/md11114628

Plouguerné, E., Ioannou, E., Georgantea, P., Vagias, C., Roussis, V., Hellio, C., et al. (2010). Anti-microfouling activity of lipidic metabolites from the invasive brown alga Sargassum muticum (Yendo) Fensholt. Mar. Biotechnol. 12, 52-61. doi: 10.1007/s10126-009-9199-9

Raposo, M. F. D., de Morais, R., and de Morais, A. (2013). Health applications of bioactive compounds from marine microalgae. Life Sci. 93, 479-486. doi: 10.1016/j.lfs.2013.08.002

Sanina, N. M., Goncharova, S. N., and Kostetsky, E. Y. (2004). Fatty acid composition of individual polar lipid classes from marine macrophytes. Phytochemistry 65, 721-730. doi: 10.1016/j.phytochem.2004.01.013

Sanina, N. M., Kostetsky, E. Y., and Goncharova, S. N. (2000). Thermotropic behaviour of membrane lipids from brown marine alga Laminaria japonica. Biochem. Soc. Trans. 28, 894-897. doi: 10.1042/BST0280894

Tsai, C.-J., and Pan, B. S. (2012). Identification of sulfoglycolipid bioactivities and characteristic fatty acids of marine macroalgae. J. Agr. Food Chem. 60, 8404-8410. doi: 10.1021/jf302241d

Wang, H., Li, Y. L., Shen, W. Z., Rui, W., Ma, X. J., and Cen, Y. Z. (2007) Antiviral activity of a sulfoquinovosyldiacylglycerol (SQDG) compound isolated from the green alga Caulerpla racemosa. Bot. Mar. 50, 185-190. doi: 10.1515/BOT.2007.022

Wu, W., Hasumi, K., Peng, H., Hu, X., Wang, X., and Bao, B. (2009). Fibrinolytic compounds isolated from a brown alga, Sargassum fulvellum. Mar. Drugs 7, 85-94. doi: 10.3390/md7020085

Zhang, J., Li, C., Yu, G., and Guan, H. (2014). Total synthesis and structure-activity relationship of glycoglycerolipids from marine organisms. Mar. Drugs 12, 3634-3659. doi: 10.3390/md12063634

Conflict of Interest Statement: The authors declare that the research was conducted in the absence of any commercial or financial relationships that could be construed as a potential conflict of interest.

Received: 10 July 2014; accepted: 24 November 2014; published online: 17 December 2014.

Citation: Plouguerné E, da Gama BAP, Pereira RC and Barreto-Bergter E (2014) Glycolipids from seaweeds and their potential biotechnological applications. Front. Cell. Infect. Microbiol. 4:174. doi: 10.3389/fcimb.2014.00174

This article was submitted to the journal Frontiers in Cellular and Infection Microbiology.

Copyright (C) 2014 Plouguerné, da Gama, Pereira and Barreto-Bergter. This is an open-access article distributed under the terms of the Creative Commons Attribution License (CC BY). The use, distribution or reproduction in other forums is permitted, provided the original author(s) or licensor are credited and that the original publication in this journal is cited, in accordance with accepted academic practice. No use, distribution or reproduction is permitted which does not comply with these terms. 